УДК 616.329-002:616-018

DOI: $10.24061 / 1727-0847.19 .4 .2020 .51$

\title{
I.В. Шкварковський
}

Кафедра хірургії № 2 (зав. - проф. А.Г. Іфтодій) Буковинського державного медичного університету, м. Чернівиі

\section{СПОСІБ ГЕРНІОПЛАСТИКИ}

Резюме. Аутопластика пахвинних гриж супроводжується високою частотою рецидиву захворювання - 10-12\%. Тому основним принципом хірургічного лікування гриж в теперішній час є виконання пластики “без натягу” з використанням сучасних синтетичних матеріалів. Однак при будь-якому виді алопласти-ки, не дивлячись на інертність синтетичного матеріалу, навколо нього розвивається тканинна реакція з вираженим запальним компонентом, що спричинює ряд специфічних ускладнень. Серед них - сероми, гематоми, відчуття стороннього тіла, синдром хронічно-го пахвинного болю. Водночас зростає кількість повідомлень про ризик виникнення специфічних ускладнень внаслідок контакту алотрансплантата із сім'яним канатиком. В основу даного дослідження покладено результати топографоанатомічного дослідження 50 нефіксованих трупів чоловіків в першу добу після смерті віком від 34 до 65 років, зростом від 160,0 до 190,0 см. Проводились морфологічні дослідження фасціально-сухожилкових елементів пахвинного каналу, вивчалась можливість транслокації сім'яного канатика в передочеревинний простір та спосіб фіксації алотрансплантата. Запропонований спосіб використовується таким чином. Косим розрізом у пахвинній ділянці вище та при середньо від пахвинної складки розсікають шкіру та підшкірну клітковину. Виділяють та розкривають апоневроз зовнішнього косого м'яза живота. Диференціюють та виділяють грижовий мішок. При косій грижі останній прошивають біля шийки, залишок відсікають. При прямій грижі грижовий мішок, не розкриваючи, занурюють у передочеревинний простір. Розсікають поперечну фасцію від внутрішнього отвору пахвинного каналу до зовнішнього краю піхви прямого м’яза живота. Сім'яний канатик після мобілізації розташовують у передочеревинному просторі, а краї поперечної фасції зшивають безперервним швом 3 ліквідацією внутрішнього отвору пахвинного каналу. Формують нове місце виходу сім'яного канатика біля бічного краю піхви прямого м’яза живота. Виконують пластику грижового дефекту за допомогою сітчастого імплантата, по верхньому краю якого формують вирізку, розмір якої відповідає діаметру сім’яного канатика. Запропонований спосіб попереджує контакт сім'яного канатика з алопротезом, попере-джуючи тим самим розвиток специфічних ускладнень. Крім цього, ушивання глибокого пахвинного кільця, як одного з найслабкіших місць пахвинного каналу, попереджує розви-ток рецидиву грижі.

Ключові слова: пахвинна грижа, полімерний імплантат.

Частота пахвинних гриж становить 5\% від усіх хірургічних захворювань, вони виявляються переважно в осіб чоловічої статі працездатного віку [1], а грижесічення є найбільш частою операцією в плановій хірургії і становить 5-10\% від загальної кількості $[1,2]$.

Аутопластика пахвинних гриж супроводжується високою частотою рецидиву захворювання - 10-12\% [1-3]. Тому основним принципом хірургічного лікування гриж в теперішній час $є$ виконання пластики “без натягу” з використанням сучасних синтетичних матеріалів [1,2]. Однак при будь-якому виді алопластики, не дивлячись на інертність синтетичного матеріалу, навколо нього розвивається тканинна реакція з вираженим запальним компонентом, що спричинює ряд специфічних ускладнень. Серед них - сероми, гематоми, відчуття стороннього тіла, синдром хронічного пахвинного болю $[2,4]$. Водночас зростає кількість повідомлень про ризик виникнення специфічних ускладнень внаслідок контакту алотрансплантата із сім'яним канатиком [5].

Останнім часом запропоновано та впроваджено багаточисленні модифікації класичної операції Ліхтенштейна. Розроблено ряд методик, що передбачають ізоляцію сім'яного канатика від алопластичного матеріалу власними тканинами (апоневрозом зовнішнього косого м'яза живота або поперечною фасцією). Тому залишається відкритим питання місця розташування алотрансплантата [5].

Мета дослідження: розробка нового способу хірургічного лікування пахвинних гриж, який передбачає розмежування полімерного імплантата 
та сім'яного канатика.

Матеріал і методи. В основу даного дослідження покладено результати топографоанатомічного дослідження 50 нефіксованих трупів чоловіків в першу добу після смерті віком від 34 до 65 років, зростом від 160,0 до 190,0 см. Проводились морфологічні дослідження фасиіально-сухожилкових елементів пахвинного каналу, вивчалась можливість транслокації сім'яного канатика в передочеревинний простір та спосіб фіксаиії алотрансплантата.

Результати дослідження та їх обговорення. На основі топографоанатомічних досліджень нами розроблено спосіб пахвинної герніопластики (деклараційний патент України на корисну модель № 81728 “Спосіб фіксації сітчастого імплантату при хірургічному лікуванні пахвинних гриж”, опублікований 10.07.2013, бюлетень № 13).

Запропонований спосіб використовується таким чином. Косим розрізом у пахвинній ділянці вище та при середньо від пахвинної складки розсікають шкіру та підшкірну клітковину. Виділяють та розкривають апоневроз зовнішнього косого м'яза живота. Диференціюють та виділяють грижовий мішок. При косій грижі останній прошивають біля шийки, залишок відсікають. При прямій грижі грижовий мішок, не розкриваючи, занурюють у передочеревинний простір. Розсікають поперечну фасцію від внутрішнього отвору пахвинного каналу до зовнішнього краю піхви прямого м'яза живота. Сім'яний канатик після мобілізації розташовують у передочеревинному просторі, а краї поперечної фасції зшивають безперервним швом 3 ліквідацією внутрішнього отвору пахвинного каналу. Формують нове місце виходу сім'яного канатика біля бічного краю піхви прямого м'яза живота. Виконують пластику грижового дефекту за допомогою сітчастого імплантата, по верхньому краю якого формують вирізку, розмір якої відповідає діаметру сім'яного канатика.

Сітчастий імплантат розташовують на поперечній фасції, заводячи верхній край під поперечний м'яз живота. Фіксацію починають 3 підши- вання нижнього краю імплантата вузловими швами до пахвинної зв'язки, особливу увагу приділяючи фіксації нижнього присереднього кута до лобкового горбика. Бічний та верхній край сітки фіксують за допомогою П-подібних швів $з$ інтервалом 1,5 см, які проводять через апоневроз зовнішнього косого м'яза живота, внутрішній косий та поперечний м'язи живота і зав'язують на зовнішній поверхні апоневрозу зовнішнього косого м'яза живота. Такою фіксацією, на наш погляд, досягається максимальне розтягнення і розправлення сітки. Присередній край імплантата фіксують до задньої поверхні піхви прямого м'яза живота таким чином, що б сім'яний канатик розташовувався у сформованій вирізці. Розріз сітки додатково укріплюють окремими вузловими швами. Для виокремлення полімерного матеріалу від елементів сім'яного канатика використовують залишки поперечної фасції. Краї апоневрозу зовнішнього косого м'яза живота зшивають обвивним швом.

Використання запропонованого способу фіксації сітчастого імплантату при хірургічному лікуванні пахвинних гриж має ряд переваг. По-перше, запропонована методика попереджує контакт сім'яного канатика $з$ алопротезом, запобігаючи розвитку рубцево-атрофічних ускладнень. По-друге, ліквідація внутрішнього пахвинного кільця, як одного 3 найслабших місць пахвинного каналу, попереджує розвиток рецидиву грижі. Потретє, фіксація сітки за допомогою П-подібних швів до поперечного, внутрішнього косого м'язів живота та апоневрозу зовнішнього косого м'яза живота запобігає гофруванню та міграції протеза.

Висновок. Запропонований спосіб попереджує контакт сім'яного канатика 3 алопротезом, попереджуючи тим самим розвиток специфічних ускладнень. Крім цього, ушивання глибокого пахвинного кільця, як одного з найслабкіших місць пахвинного каналу, попереджує розвиток рецидиву грижі.

Перспективи подальших досліджень. Порівняльне вивчення ефективності запропонованого способу пахвинної герніопластики із застосуванням різних типів алотрансплантатів.

\section{Список використаної літератури}

1. Ахмед ММ. Хирургическое лечение больных с паховой грыжей. Хірург. Украӥни: 2012;(2): 99-107.

2. Сидорчук РІ, Кнут РП, Плегуца ОМ. Метод функиіонально-адаптивної фіксаиії алотрансплантата у пахвинній герніопластиці. Чернівиі: БДМУ, 2011. 244 c.

3. Глодан ОЯ. Вплив на сперматогенез тривалої фіксаиії сім'яного канатика під час пластики пахвинного каналу. Клін. та експеримент. патолог. 2009;30(4):20-2.

4. Грииуляк БВ, Грииуляк ВБ, Халло ОС. Гістоультраструктура звивистих сім'яних трубочок яєчка після пластики задньої стінки пахвинного каналу. Клін. анатом. та оператив. хірург. 2009;8(4):43-5.

5. Власов ВВ, Бабій IB, Мельничук ОІ. Передочеревинна алопластика пахвинної грижі. Aсtа Меdica 
2. Sydorchuk RI, Knut RP, Plehutsa OM. Metod funktsional'no-adaptyvnoyi fiksatsiyi alotrans-plantata u pakhvynniy hernioplastytsi. Chernivtsi: BDMU, 2011. 244 s.

3. Hlodan OYA. Vplyv na spermatohenez tryvaloyi fiksatsiyi sim"yanoho kanatyka pid chas plastyky pakhvynnoho kanalu. Klin. ta eksperyment. patoloh. 2009;30(4):20-2.

4. Hrytsulyak BV, Hrytsulyak VB, Khallo OYE. Histoul'trastruktura zvyvystykh sim"yanykh trubochok yayechka pislya plastyky zadn'oyi stinky pakhvynnoho kanalu. Klin. anatom. ta operatyv. khirurh. 2009;8(4):43-5.

5. Vlasov VV, Babiy IV, Mel'nychuk OI. Peredocherevynna aloplastyka pakhvynnoyi hryzhi. Acta Medica Leopoliencia. 2009;(3):43-6.

\section{СПОСОБ ГЕРНИОПЛАСТИКИ}

Резюме. Аутопластика паховых грыж сопровождается высокой частотой рецидива заболевания - 10 $12 \%$. Поэтому основным принципом хирургического лечения грыж в настоящее время является выполнение пластики "без натяжения" с использованием современных синтетических материалов. Однако при любом виде алопластики, несмотря на инертность синтетического материала, вокруг него развивается тканевая реакция с выраженным воспалительным компонентом, вызывает ряд специфических осложнений. Среди них - серомы, гематомы, ощущение инородного тела, синдром хронической паховой боли. В то же время растет число сообщений о риске возникновения спе-цифичних осложнений вследствие контакта аллотрансплантата с семенного канатика. В основу данного исследования положены результаты топографоанатомическом исследования 50 нефиксированных трупов мужчин в первые сутки после смерти в возрасте от 34 до 65 лет, ростом от 160,0 до 190,0 см. Проводились морфологические исследования фасциально-сухожильных элементов пахового канала, изучалась возможность транслокации семенного канатика в передочеревинного пространство и способ фиксации аллотрансплантата. Предложенный способ используется следующим образом. Косым разрезом в паховой области выше и при средне от паховой складки рассекают кожу и подкожную клетчатку. Выделяют и раскрывают апоневроз наружной косой мышцы живота. Дифференцируют и выделяют грыжевой мешок. При косой грыжи последний прошивают у шейки, остаток отсекают. При прямой грыжи грыжевой мешок, не раскрывая, погружают в передочеревинного пространство. Рассекают поперечную фасцию от внутреннего отверстия пахового канала к внешнему краю влагалища прямой мышцы живота. Семенной канатик после мобилизации располагают в передочеревинного пространстве, а края поперечной фасции сшивают непрерывным швом с ликвидацией внутреннего отверстия пахового канала. Формируют новое место выхода семенного канатика у бокового края влагалища прямой мышцы живота. Выполняют пластику грыжевого дефекта с помощью сетчатого имплантата, по верхнему краю которого формируют вырезку, размер которой соответствует диаметру семенного канатика. Предложенный способ предупреждает контакт семенного канатика с алопротезом, предупреждая тем самым развитие специфических осложнений. Кроме этого, ушивание глубокого пахового кольца, как одного из самых слабых мест пахового канала, предупреждает развитие рецидива грыжи.

Ключевые слова: паховая грыжа, полимерный имплантат.

\section{HERNIOPLASTY METHOD}

Abstract. Autoplasty of inguinal hernias is accompanied by a high recurrence rate of the disease - 10-12\%. Therefore, the main principle of surgical treatment of hernias at the present time is the performance of plastics "without tension" using modern synthetic materials. However, in any type of aloplasty, despite the inertness of the synthetic material, a tissue reaction with a pronounced inflammatory component develops around it, causing a number of specific complications. Among them are seromas, hematomas, foreign body sensation, chronic groin pain syndrome. At the same time, there is an increasing number of reports on the risk of specific complications due to contact of the allograft with the spermatic cord. This study is based on the results of a topographic and anatomical study of 50 unfixed corpses of men on the first day after death at the age of 34 to 65 years, with a height of 160.0 to $190.0 \mathrm{~cm}$. cord into the anterior rectal space and the method of fixing the allograft. The proposed method is used as follows. An oblique incision in the groin area above and in the middle of the groin folds cut through the skin and subcutaneous tissue. The aponeurosis of the external oblique 
abdominal muscle is isolated and opened. The hernial sac is differentiated and isolated. With an oblique hernia, the latter is stitched at the neck, the remainder is cut off. With a direct hernia, the hernial sac, without opening, is immersed in the anterior urethral space. The transverse fascia is dissected from the inner opening of the inguinal canal to the outer edge of the rectus sheath. After mobilization, the spermatic cord is placed in the anterior ureal space, and the edges of the transverse fascia are sutured with a continuous suture with the elimination of the inner opening of the inguinal canal. A new exit site of the spermatic cord is formed at the lateral edge of the sheath of the rectus abdominis muscle. Plasty of the hernial defect is performed using a mesh implant, along the upper edge of which a notch is formed, the size of which corresponds to the diameter of the spermatic cord. The proposed method prevents the contact of the spermatic cord with the aloprosthesis, thereby preventing the development of specific complications. In addition, suturing the deep inguinal ring, as one of the weakest points of the inguinal canal, prevents the development of hernia recurrence.

Key words: inguinal hernia, polymer implant.

Відомості про автора:

Шкварковський Ігор Володимирович - доктор медичних наук, професор, професор кафедри хірургії № 2 Буковинського державного медичного університету, м. Чернівці.

Information about author:

Shkvarkovskyi Ihor Volodymyrovych - Doctor of Medical Sciences, Professor of the Department of Surgery № 2 of Bukovinian State Medical University, Chernivtsi.

Надійшла 02.10.2020 p.

Рецензент - проф. Максимюк В.В. (Чернівці) 